hvordan vi som spesialister skal veilede nye generasjoner. Min overbevisning etter dette er at potensialet i veilederfunksjonen er undervurdert og at vi kunne ha fătt en enda mer fokusert og effektiv utdanning om veilederne var mer bevisst sin rolle og hadde den nødvendige pedagogiske innsikten.

Boken anbefales til alle som er i spesialisering, ferdige spesialister som fungerer som veiledere og også ledere i helsevesenet som setter rammevilkårene for utdanning. Personlig anser jeg boken som et viktig bidrag til en dypere forståelse for de utfordringene spesialistutdanningen har og at vi i Norge har mye å lære fra svenske forhold på dette området.

Tom Glomsaker

Kirurgisk avdeling

Stavanger universitetssjukehus

\section{Informativt om meditasjon}

Davanger S, Eifring $\mathrm{H}$, Hersoug $A G$, red Fighting stress

Reviews of meditation research. $191 \mathrm{~s}$, ill. Oslo: Acem Publishing, 2008. Pris NOK 95 ISBN 978-82-91-40516-2

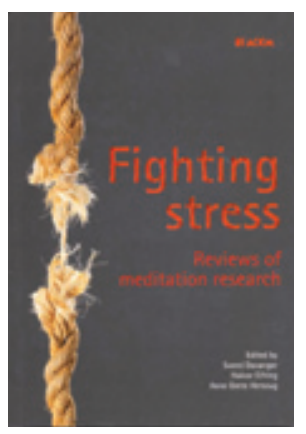

Fighting stress er en samling artikler om meditasjon skrevet av en gruppe nordiske forfattere. Det er en populærvitenskapelig bok beregnet på den opplyste allmennhet, men den kan leses med utbytte også av personer med helsefaglig utdanning, herunder leger. De fleste av innleggene er litteraturoversikter, men det er også presentasjoner av forskningsprosjekter og gjennomgang av et norsk doktorgradsarbeid.

Meditasjon har vært benyttet for ulike tilstander, fra å bedre idrettsprestasjoner, mestring av psykologiske og kroppslige reaksjoner på stress til behandling av psykiske og psykosomatiske lidelser i form av angst, depresjon, kroniske smerter, forhøyet blodtrykk og ugunstig lipidprofil. Her gjennomgås den foreliggende forskning som bakgrunn for å anbefale meditasjon ved ulike tilstander. Graden av vitenskapelig kunnskapsgrunnlag er varierende, men gjennomgående begrenset. Det er for eksempel få studier som har undersøkt mennesker med diagnostiserte psykiske lidelser. Det er også artikler om mulige virkningsmekanismer, fra endokrinologi til nevrobiologi.

Layouten er fin, med bilder og illustrasjoner som hever kvaliteten, og teksten er for det meste godt skrevet og lettlest. For meg var dette en god innføring i et fagfelt som jeg hadde begrenset kunnskap om.

Boken er skrevet av personer som brenner for temaet, slik det ofte er for tiltak utenfor den snevre skolemedisin. Alle forfatterne er instruktører i Acem. Det er enkelt å trekke paralleller til en annen selvhjelpsmetode: fysisk aktivitet. Ved begge disse tiltakene er forskningen initiert og til dels gjennomført av entusiaster, og midler til forskning er begrenset. Fighting stress er ingen lærebok i meditasjon, men den beskriver ulike former for meditasjon og deres helsegevinster samt hvordan meditasjon kan læres i Acem-systemet. Det er for tiden stor interesse innen det psykiatriske fagfeltet for fenomener som «mindfulness», mentalisering og metakognitiv terapi, og meditasjon er en selvhjelpsmetode som har en plass innenfor dette området.

Til tross for en storstilt utbygging av helsevesenets tilbud, er det fortsatt et stort behov for virksomme selvhjelpsmetoder. Meditasjon ser ut til å være en slik strategi, som i denne lille boken presenteres på en lett tilgjengelig måte.

\section{Egil W. Martinsen}

Klinikk for psykisk helse

Oslo universitetssykehus, Aker

\section{Gårsdagens barn er dagens mødre og fedre}

Crittenden PM.

Raising parents

Attachment, parenting and child safety. $380 \mathrm{~s}$ tab, ill. Devon: Willan Publishing, 2008. Pris GBP 30

ISBN 978-1-84392-498-2

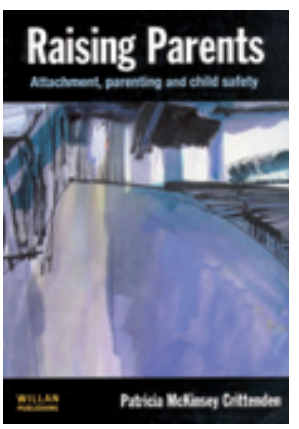

Både i klinisk praksis og forskning har et av Pat Crittendens hovedtema vært forutsetninger for og betydningen av tilknytningsforhold. Med utgangspunkt i arbeidene til Mary D. Ainsworth (1913-99) og John Bowlby (1907-90) har hun utviklet «The dynamic-maturational modell» (DMM) for tilknytning og adaptasjon. Den integrerer tilknytningsteori og systemisk teori med kognitiv nevrovitenskap og genetikk.

Modellen er for livslang utvikling der pågående modning er i en dynamisk interaksjon med erfaring. Tidlig erfaring påvirker senere utvikling, men er ikke bestemmende for den. Modning skaper nemlig mulighet hos personen for reorgani- sering, nye strategier og ny informasjon om verden og dem selv.

Modellen danner grunnlaget for analysene og terapianbefalingene $\mathrm{i}$ boken, som retter seg mot psykologer og barne- og ungdomspsykiatere som arbeider med barn, ungdom og foreldre som ble skadet som barn. Den handler om foreldre som er til fare for sine barn og hvis barn kan være til fare for seg selv eller andre, dvs. barn i grenselandet mellom barnevern og barneog ungdomspsykiatri.

Boken er delt i tre hovedavsnitt. Vokse opp analyserer med eksempler fra farlig og voldelig foreldreatferd de ulike selvbeskyttende strategiene barnet utvikler og hvordan de med kognitiv modning og erfaring kan endre seg til komplekse og uheldige strategier. Oppdra barn har to formål. På den ene siden gir forfatteren et perspektiv på hvorfor foreldre som skader sine barn i oppveksten gjør som de gjør. På den annen side viser forfatteren hva slags atferdsmønstre og psykiske vansker økende grad av barnemishandling kan påføre barn. I En integrert tilnoerming til behandling utvikler forfatteren en overordnet terapiteori der hun kombinerer eksisterende terapiteorier, men samtidig gir retningslinjer for når og med hvem de forskjellige teknikkene sannsynligvis gir best resultat.

Teori og klinisk praksis er knyttet sammen med kasuistikker, og dette gjør boken både mer lettlest og det teoretiske stoffet mer tilgjengelig. Den er ryddig redigert, med oversiktlig layout. Den kan anbefales på det varmeste også fordi den er gjennomsyret av en vilje til å forstå og vise respekt for foreldre som svikter så totalt i sin foreldrerolle. Crittenden hevder at det å forstå at foreldre både kan være ofre og gjerningsmenn, er avgjørende for å kunne hjelpe både foreldre og barn. Det er en viktig påminning til alle som arbeider i feltet.

\section{Marit Hafting}

Regionsenter for barn og unges psykiske helse, Helse Vest

Universitetet i Bergen 